\title{
Size independent selective filtration of ultraplankton by hexactinellid glass sponges
}

\author{
Gitai Yahel $^{1, *}$, Dafne I. Eerkes-Medrano ${ }^{1,3}$, Sally P. Leys ${ }^{2}$ \\ ${ }^{1}$ Department of Biology, University of Victoria, PO Box 3020 Stn CSC, Victoria, British Columbia V8W 3N5, Canada \\ ${ }^{2}$ Department of Biological Sciences, CW 405, Department of Biological Sciences, University of Alberta, Edmonton, \\ Alberta T6G 2E9, Canada \\ ${ }^{3}$ Present address: Department of Zoology, Oregon State University, Corvallis, Oregon 97331-2914, USA
}

\begin{abstract}
Selective feeding by flagellate and ciliate protists is important in shaping microbial communities in pelagic habitats. While less is known of predation on microbial communities in benthic habitats, the abundance and high filtering capacity of sponges suggests that they are key grazers. We studied the feeding preferences of two of the most common glass sponges of North-East Pacific fjords, Rhabdocalyptus dawsoni and Aphrocallistes vastus. Sponges were maintained in large darkened tanks supplied with running seawater from the nearby fjord. The water inhaled and exhaled by the sponges was simultaneously sampled and analyzed using a flow cytometer. Both sponges showed a similar (but not identical) feeding pattern, efficiently removing up to $99 \%$ of the most abundant bacterial cells, whereas clays, silt, and 'debris' particles were expelled into the exhaled water. Filtration efficiencies were maximal for the relatively large and rare eukaryotic algae ( 3 to $5 \mu \mathrm{m}, 86 \pm 9 \%$ ) and for small non-photosynthetic bacteria $(<0.4 \mu \mathrm{m}, 89 \pm 10 \%)$, while intermediate sized non-photosynthetic bacteria characterized by higher nucleic acid content were efficiently removed in February $(92 \pm 3 \%)$ when overall plankton concentration was low, but not in July $(28 \pm 16 \%)$. The intermediate sized photosynthetic prokaryote Synechococcus $(1.1$ to $1.5 \mu \mathrm{m})$ was also less preferred. Detailed analysis of the ultrastructure of the glass sponge filtration apparatus argues against possible 'by-pass' routes. We suggest that selective filtration involves individual processing, recognition, sorting, and transport of each particle through the sponges' syncytial tissue. Selective grazing by glass sponges, like their pelagic protozoan counterparts, could be an important mechanism shaping microbial communities in the detrital food web of North-East Pacific fjords.
\end{abstract}

KEY WORDS: Selective feeding $\cdot$ Filtration $\cdot$ Aphrocallistes vastus $\cdot$ Rhabdocalyptus dawsoni

Resale or republication not permitted without written consent of the publisher

\section{INTRODUCTION}

Selective feeding is an important mechanism by which animals optimize their diet, e.g. by maximizing their energy gain or avoiding harmful food. It is well documented that selective predation in pelagic habitats structures the microbial community (Pernthaler 2005). Less is known of interactions in benthic habitats. At the benthic boundary layer, microbial communities take advantage of an enhanced flux of nutrients and organic matter (Gast et al. 1998, van Duyl \& Gast 2001, Seymour et al. 2005), but at the same time they are exposed to enhanced predation by benthic sus- pension feeders (Pile 1997, Yahel et al. 1998, Scheffers et al. 2005). Sponges are key grazers in many benthic habitats (Diaz \& Rutzler 2001, Richter et al. 2001, Ribes et al. 2005, Scheffers et al. 2005). Although we now know that many benthic suspension feeders, such as bivalves, are selective in their diet (Cranford \& Gordon 1992, Ward \& Shumway 2004), the notion that sponges can selectively ingest food from the water they filter is not well acknowledged, despite a growing number of studies to support this (Jørgensen 1966, Reiswig 1971, Frost 1980, Wilkinson et al. 1984, Vyver et al. 1985, Pile et al. 1996, Turon et al. 1997, Ribes et al. 1999). 
Sponges are reported to have a wide spectrum of nutritional strategies, including uptake of dissolved organic matter (Wilkinson \& Garrone 1980, Reiswig 1981, Yahel et al. 2003), complex symbiotic associations with phototrophic (Sara 1971, Wilkinson 1983) and chemosynthetic microorganisms (Diaz \& Ward 1997, Hoffmann et al. 2005) and even carnivory (Vacelet et al. 1995). However, sponges are widely recognized as efficient filter feeders, feeding primarily on micron sized prokaryotic prey (Jørgensen 1966, Reiswig 1971, 1975b, Gili et al. 1984, Wilkinson et al. 1984). More recent studies have shown that ultraphytoplankton $(<10 \mu \mathrm{m})$ is also a major constituent of the diet of marine demosponges from shallow waters (Pile 1997, Ribes et al. 1999, Pile et al. 2003, Yahel et al. 2003).

The sponge body consists of extensive water canals and chambers. A single layer of cells (choanocytes), lining the surface of densely packed spherical chambers, creates a unidirectional water current which carries oxygen and food particles and removes wastes (Jørgensen 1966). Sponges filter vast volumes of water (60 to 900 times their volume per hour, reviewed by Yahel et al. 2003). In some marine and freshwater environments they are the principal filter-feeding macroinvertebrates (Pile et al. 1997, Richter et al. 2001, Scheffers 2005), leading to the suggestion that feeding by sponges has a great effect on benthic-pelagic processes (Richter et al. 2001, Ribes et al. 2005, Yahel et al. 2007).

Glass sponges (class Hexactinellida) prefer deeper water $(>100 \mathrm{~m})$ worldwide, and in some locations (e.g. Antarctica, and coastal North East Pacific) meter tall glass sponges form the bulk of the filter-feeding population, sometimes reaching densities of tens of individuals $\mathrm{m}^{-2}$ (Dayton et al. 1974, Conway et al. 2001, Leys et al. 2004). Glass sponges also dominated ancient deepsea habitats, forming reefs over $700 \mathrm{~km}^{2}$ in the Tethys Sea during the Jurassic (Ghiold 1991, reviewed in Krautter et al. 2001). Despite the potential importance of glass sponge feeding in present and past deep-sea habitats, few studies have examined their diet and the role of glass sponges in benthic-pelagic coupling, in large part due to the difficulty of working at depth.

In the Northeast Pacific, glass sponges dominate fjord and inlet walls below the photic zone (Leys et al. 2004) and in some places form extensive bioherms (sponge reefs, Conway et al. 1991). However, their distribution is limited to deeper waters $(>25 \mathrm{~m})$. The factor(s) limiting the vertical distribution of the glass sponges are not yet understood, but food availability has been implicated as one possible factor (Leys et al. 2004). In a pioneering in situ feeding study, Reiswig (1990) reported that 2 species of glass sponge, Rhabdocalyptus dawsoni (Lambe, 1892) and Aphrocallistes vastus (Schulze 1886), may have very different reten- tion efficiencies for bacteria ( 0 and $18 \%$, respectively), and that $R$. dawsoni may rely largely on dissolved organic carbon. These results suggested that glass sponges have significantly different feeding strategies than demosponges; however, high variance, due to disturbance to the water surrounding the specimens while sampling and to the unpredictable pumping activity of $R$. dawsoni, meant that the data was inconclusive. More recently, ultrastructural studies by Perez (1996) and Wyeth (1999) showed that glass sponges can efficiently retain micron sized beads and bacteria, like their demosponge relatives. Most recently, Yahel et al. (2007) used a remotely operated submersible to study glass sponge feeding in their deep habitat $(150 \mathrm{~m})$ on the walls of a North-East Pacific fjord. Both species fed primarily on non-photosynthetic bacteria and small protozoans with no evidence for uptake of dissolved organic matter or detritus. The calculations of Yahel et al. (2007) suggest that the glass sponge population in a typical North-East Pacific fjord may annually filter an amount of water equivalent to the entire volume of the fjord water, thereby processing $>20 \%$ of the carbon exported into the deep fjord waters each year.

In situ studies have the advantage of identifying uptake of food by sponges in their natural habitat, but do not demonstrate whether the animals are capable of taking up other particles at other times or under other conditions. To test the range of sponge feeding selectivity for different particle types, the filter-feeding abilities of Rhabdocalyptus dawsoni and Aphrocallistes vastus were examined in a controlled environment in which the sponges experienced minimal disturbance. By drawing water from Bamfield Inlet, British Columbia, Canada, the sponges were presented with a variety of naturally occurring food particles, including photosynthetic populations naturally available only to the uppermost sponge populations.

\section{MATERIALS AND METHODS}

Study organisms. Rhabdocalyptus dawsoni (Lambe, 1892) and Aphrocallistes vastus Schulze 1886 co-occur in fjord habitats, with $R$. dawsoni reaching slightly shallower depths (up to $18 \mathrm{~m}$; Leys et al. 2004) than A. vastus. The 2 sponges differ significantly in the nature of their outer covering. Spicules projecting from the outer surface of $R$. dawsoni are brown with accumulated sediment forming a 'spicule coat' that is inhabited by numerous epi-fauna and epi-flora (Boyd 1981). In contrast, A. vastus has a clean outer surface. Both species lack conspicuous populations of symbiotic bacteria (Reiswig 1979, Mackie \& Singla 1983). In their natural habitat, on vertical walls, R. dawsoni tends to be confined to the 
benthic boundary layer; the body lies within $10 \mathrm{~cm}$ of the wall and the osculum projects only $20 \mathrm{~cm}$ off the wall. In contrast, $A$. vastus typically extends up to $1 \mathrm{~m}$ away from the wall. Both $R$. dawsoni and $A$. vastus cease feeding when exposed to heavy sediment loads. However, while A. vastus appears to be fairly refractory to disturbance, arresting pumping only momentarily, arrests by $R$. dawsoni are typically much longer (minutes to hours, Leys \& Tompkins 2004).

All specimens were collected from the vertical walls of an underwater canyon near San Hosie Islets $\left(48^{\circ} 54.261^{\prime} \mathrm{N}, 125^{\circ} 2.6358^{\prime} \mathrm{W}\right)$, Barkley Sound, Vancouver Island, British Columbia, Canada. Both glass sponge species attach to the walls by a silica base (Leys \& Lauzon 1998). Aphrocallistes vastus was collected from a depth of 130 to $170 \mathrm{~m}$ using a remotely operated from vehicle; intact specimens were carefully detached from the wall at their base using the manipulator arms. Specimens of Rhabdocalyptus dawsoni were collected by SCUBA divers from 25 to $30 \mathrm{~m}$ in February and July 2004. In both cases, sponges were promptly transferred, without removal from cold seawater at any time, to darkened aquaria at the Bamfield Marine Sciences Center.

Five individuals of each species were arranged in a large tank $(1.70 \times 0.75 \times 0.22 \mathrm{~m})$. Previous studies have indicated that glass sponges only do well if supplied with fresh running seawater (Wyeth et al. 1996, Leys et al. 1999). Therefore, the experimental tank was equipped with a constant supply of running seawater pumped from the nearby Bamfield Inlet $(25 \mathrm{~m}$ depth, $\sim 2 \mathrm{~m}$ above bottom). Water temperature ranged from 9 to 10 and 12 to $13^{\circ} \mathrm{C}$ and water salinity was 26.5 and 29.5 in February and July, respectively. We used 3 inflow water hoses and vigorous water flow $\left(20 \mathrm{l} \mathrm{min}^{-1}\right.$ per hose) to ensure short residence time $(<5 \mathrm{~min})$ and thorough mixing of tank water to minimize the effect of sponge feeding on ambient water. The specimens of Rhabdocalyptus dawsoni ranged in length from 12 to $19 \mathrm{~cm}$ with oscula internal diameter of 1.5 to $2.5 \mathrm{~cm}$, while specimens of Aphrocallistes vastus were 12 to $36 \mathrm{~cm}$ long with oscula 2 to $15 \mathrm{~cm}$ in diameter.

Water sampling. In order to measure the sponge filtration efficiency we compared the contents of the water inhaled and exhaled by the sponge using the direct method of Wright \& Stephens (1978). Small tubing was used to simultaneously siphon the water inhaled (ambient) and exhaled by the sponge. The difference in concentrations of a certain substance between a pair of samples provides a direct measure of the retention (or production) of the substance by the animal. Stainless wire wrapped around the tubing allowed precise positioning of the ends of the tubing $1 \mathrm{~cm}$ in the osculum of each sponge to collect exhaled water. Separate pieces of tubing were positioned adjacent to the sponges to collect ambient (inhaled) water. Retort stands and lab clamps held the tubing in place, such that water could be sampled continuously from the sponges without the need to move either tubing or sponges. At no point did the tubing make contact with the sponges. To avoid contamination of exhaled water with ambient water (Yahel et al. 2005) we used Tygon tubing with an internal diameter of $0.79 \mathrm{~mm}$ and $\sim 1 \mathrm{~m}$ in length. Suction was initiated by a syringe and continued by gravitation. Sampling vessels were located in an ice bath outside of the tank, $\sim 30 \mathrm{~cm}$ below the water surface. This setup ensured a slow suction rate $\left(<1.5 \mathrm{ml} \mathrm{min}^{-1}\right), 2$ orders of magnitude slower than the sponge pumping rate (use of fluorescein dye to visualize pumping by the sponges indicated that excurrent flow rate was always $>100 \mathrm{ml}$ $\min ^{-1}$ ). The pumping activity of each specimen sampled was visualized using fluorescein dye during the initial setup of the sponges, 60 and $20 \mathrm{~min}$ before water samples were collected, and directly after collection of water samples. Water samples were collected into sterile $500 \mathrm{ml}$ glass bottles (February) or directly into $2 \mathrm{ml}$ cryotubes (July). Samples were preserved using $0.4 \%$ glutaraldehyde (final concentration, 15 min incubation in room temperature), frozen in liquid nitrogen and stored at $-80^{\circ} \mathrm{C}$.

Flow cytometry. For analysis by flow cytometry, we followed the protocol of Marie et al. (1999), using a $488 \mathrm{~nm}$, air-cooled Argon-ion laser flow cytometer (FACSCalibur, Becton Dickinson). Non-photosynthetic bacteria were analyzed following staining with the nucleic acid dye SYBR Green I (Molecular Probes, S-7567, Marie et al. 1997) at a final concentration of $10^{-4}$ of the commercial stock. Samples were incubated for $25 \mathrm{~min}$ in the dark at room temperature. Flow rate was set to low (6 to $8 \mu \mathrm{min}^{-1}$, measured daily) and inhaled and exhaled water samples were analyzed sequentially for 2 min each. Particles with low ratio of green fluorescence to light scatter were considered as non-living seston (NLS). Ultraphytoplankton was quantified in unstained samples using their red/orange auto-fluorescence. Particles with low ratio of red fluorescence to light scatter were considered as detritus. A unique cluster of large detrital particles (LDet) was evident in most samples. These samples were analyzed at a high flow rate $\left(60 \mu \mathrm{min}^{-1}\right)$ using low Fl3 (red fluorescence) threshold for 5 min each. Amplifications and threshold were adjusted as needed, but exhaled water samples were always analyzed after the corresponding inhaled water sample using the inhaled water sample settings. A tube containing filtered Milli-Q water was mounted in between inhaled and exhaled water samples to prevent, and control for, carryover contamination that could result in an underestimate of removal efficiency. Yellow fluorescent beads $(1 \mu \mathrm{m})$ (Flow- 
Check High Intensity Green Alignment, Polysciences, 23517) were introduced into each sample as an internal standard and all cellular parameters were normalized to the beads' value. Negative controls were run with $0.2 \mu \mathrm{m}$ filtered seawater or double distilled water with and without stain and preservative to ensure sampling integrity.

Flow cytometry data were collected in list mode using Cell Quest software. All cellular parameters were recorded on a 4 decade logarithmic scale using 1024 channels. Sample analysis and normalization to beads was done using CytoWin (Vaulot 1989, Ver. 4.31, 2003). Contour plots were made using WinMDI (J. Trotter, http://facs.scripps.edu). Forward scatter is correlated to particle size and equivalent-spherevolume. Because these relationships are roughly linear for up to $\sim 5 \mu \mathrm{m}$ particles (Robertson et al. 1998, Cavender-Bares et al. 2001), forward scatter is widely used as a relative or absolute measure of size (Cavender-Bares et al. 2001, and references therein). We report the ratio of forward scatter of particles to the forward scatter of $1 \mu \mathrm{m}$ beads in $\mu \mathrm{m}$ units. Since we neither measured the cells microscopically nor calibrated our flow cytometer measurements (Cavender-Bares et al. 2001, Shalapyonok et al. 2001), the sizes given here should be regarded as approximations, especially for larger particles $(>8 \mu \mathrm{m})$, the limit of the dynamic range used. Due to this limitation the flow cytometer counts were not transformed to cell biomass.

Sorting and microscopy. To further examine the composition of the particulate matter in the water inhaled and exhaled by the sponge, we used a Field Emission Scanning electron microscope (JOEL 6301) equipped with an Energy dispersive X-ray (EDX) Analyzer (Princeton Gamma Tech). A subset of the samples fixed for flow cytometry in July 2004 were filtered through $0.05 \mu \mathrm{m}$ Millipore filter membranes, rinsed 5 times with double distilled water, air dried (while covered to prevent accumulation of dust), and coated with chromium. Each filter was scanned at low magnification; 10 to 20 particles were selected at random and examined at high magnification. We used EDX microanalysis (Leppard et al. 1997) to determine the elemental composition of the particles $\left(\sim 1 \mu \mathrm{m}^{2}\right)$. Particles with high aluminum and silica content were recorded as clay $(<3.9 \mu \mathrm{m})$ or silt $(>3.9 \mu \mathrm{m})$. Clays were also identified visually by their characteristic edges. To clarify the identity of the LDet cluster we used a FACS Vantage flow cytometer (Becton Dickinson) equipped with an SE Turbo-Sort cell sorter. Sorted particles were filtered and examined by SEM-EDX as above.

Water samples from the February 2004 experiment were also analyzed for nitrate, phosphate, silicic acid, total organic carbon, and dissolved organic carbon. These data are reported elsewhere (Yahel et al. 2007).
Preparation of specimens for scanning electron microscopy was carried out as described in EerkesMedrano \& Leys (2006).

Statistical analysis. Statistical analysis was carried out using SPSS 12.0 for windows. Data are reported as average \pm 1 SD unless stated otherwise. In classical grazing experiments, the suspension feeder activity affects food concentrations in the experimental vessel (Chesson 1983, Riisgård 2001). Measuring direct filtration efficiency as was done here allows estimation of Chesson's selectivity index $\left(\alpha_{i}\right)$ as the maximum likelihood estimator (Case 1 in Chesson 1983):

$$
\tilde{\alpha}_{i}=F_{i}\left(\sum_{i=1}^{m} F_{i}\right)^{-1}
$$

where $m$ is the number of prey types and $F_{i}$ is the filtration efficiency for the ith prey type, calculated as $F_{i}=$ $\left(I n_{i}-E x_{i}\right) / I n_{i l}$ where $I n_{i}$ and $E x_{i}$ are the concentrations of the ith prey type in the water inhaled and exhaled by the studied sponge, respectively. A separate $\alpha_{i}$ was calculated for each paired water sample. For better visualization, $\alpha_{i}$ were rescaled to $\varepsilon_{i}$ using the equation (Chesson 1983):

$$
\varepsilon_{i}=\left(m \alpha_{i}-1\right) /\left[(m-2) \alpha_{i}+1\right]
$$

Values of $\varepsilon_{i}$ range from -1 when none of the $i$ th prey type is taken, to 1 when the $i$ th prey type is the only one selected for. However, since the statistical properties of the $\varepsilon_{i}$ are not fully resolved, statistical inference was done solely with the $\alpha_{i} \mathrm{~s}$ (Chesson 1983). To meet ANOVA requirements of homogeneity of variance and normality, filtration efficiency was square root and arcsine transformed and Chesson $\alpha_{i}$ s were square root transformed. For Repeated Measure ANOVA (RM ANOVA) we also tested the compound symmetry and sphericity assumptions (i.e. cases in which differences between levels were correlated across subjects) using Mauchly's Test of Sphericity and compared the results of the univariate test with Wilks' $\lambda$ (a multivariate criterion). The mean of each level (prey taxa) was compared to the mean of all of the levels (grand mean) using a planned comparisons 'Deviation' contrast. Post-hoc pairwise comparisons were calculated using LSD (least significant difference) adjustment for the confidence interval (95\%) of the marginal means. The terms 'selectivity' and 'preference' are used here in the narrow sense to denote differential retention.

Our comparisons of cell properties were especially robust due to the paired sampling design applied throughout sample collection and analysis (the same populations were compared in the same water prior to and after the passage via the sponge filtration apparatus using the same analytical settings). The normalization to calibration beads provided additional protection against instrumental drifts. 


\section{RESULTS}

Both Rhabdocalyptus dawsoni and Aphrocallistes vastus showed similar but not identical size independent selectivity in their feeding preferences, efficiently removing up to $99 \%$ of the cells from the smallest and most abundant bacterial population (Fig. 1A,B, Table 1) and up to $94 \%$ of the larger and rare eukary-
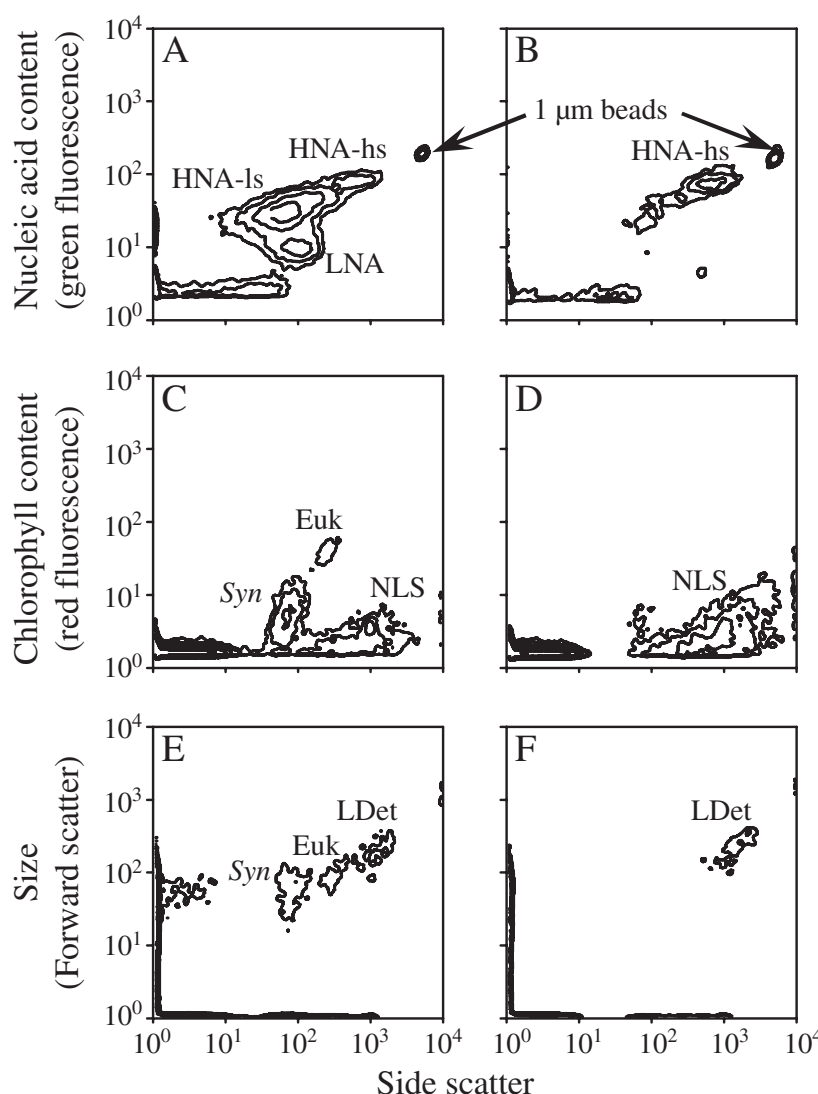

Fig. 1. A typical flow cytometry analysis, plotted on a 4 decade logarithmic scale, of a paired sample of the water $(\mathrm{A}, \mathrm{C}, \mathrm{E})$ inhaled and $(\mathrm{B}, \mathrm{D}, \mathrm{F})$ exhaled by the sponge Aphrocallistes vastus (specimen Av-D, July 2004, Run \#4). In (A) and (B) the green fluorescence (nucleic acid content) of SYBR Green stained non-photosynthetic bacteria is plotted versus their side scatter. Three populations are evident in the inhaled water whereas mostly HNA-hs (high nucleic acid content, high light scatter) cells remained in the exhaled sample. Photosynthetic cells were gated out of these plots (not shown). Non-stained particles from the same samples are shown in (C) and (D), where chlorophyll content, red fluorescence, is plotted versus side scatter, and in $(\mathrm{E})$ and $(\mathrm{F})$, where particle size (forward scatter) is plotted against their side scatter. (E) and (F) also show the LDet cluster. Both eukaryotic algae (Euk) and the cyanobacterium Synechococcus (Syn) are clearly seen in the inhaled water sample $(\mathrm{C}, \mathrm{E})$ but not in the exhaled water $(\mathrm{D}, \mathrm{F})$, where mostly non-living seston remain (NLS, sediment and detrital particles). Note that $(\mathrm{A})$ and $(\mathrm{B})$ and $(\mathrm{C}-\mathrm{F})$ were obtained from different runs of the same water sample with different settings, so the side scatter axes are not comparable between the 2 runs otic algae. Non-photosynthetic bacteria with intermediate sized cells (HNA-hs, high nucleic acid, high light scatter) were efficiently removed in February, when overall plankton concentration was low (Table 1, Figs. 2A \& 3), but not in July when plankton concentration was high. Retention efficiencies in July for HNAhs were as low as $0 \%$ (Table 1, Fig. 2B). Synechococcus cells were less preferred by $R$. dawsoni in February and by $A$. vastus in July. Comparison of $\alpha_{i}$ for the different prey items shows that the frequency of the intermediate sized taxa in the sponge diet was significantly lower than expected based on their ambient abundance, indicating negative selection. Similarly, inorganic sediment grains and debris were not retained by the sponges but rather expelled into the excurrent water (Fig. 1).

\section{Ambient ultra-plankton populations}

In a sharp contrast to deeper fjord water where most glass sponges reside (150 m, Yahel et al. 2007), phytoplankton cells and phytoplanktonic debris accounted for a large proportion of the seston in the shallower waters used for this study.

In February, prior to the initiation of the spring bloom, ultraplankton concentration was relatively low. Ultraphytoplankton (Synechococcus + eukaryotic algae) concentration was $6.8 \pm 0.3 \times 10^{3}$ cells $\mathrm{cm}^{-3}$ and nonphotosynthetic bacteria concentration was $3.7 \pm 0.4 \times$ $10^{5}$ cells $\mathrm{cm}^{-3}$. Two major bacterial populations (LNA and HNA-ls, low nucleic acid and high nucleic acid, low light scatter, respectively) comprised $97 \%$ of the non-photosynthetic bacteria. LNA cells were on average $25 \%$ smaller and their nucleic acid content was about half that of the HNA-ls cells (Fig. 1A, Table 1).

In July, ultraphytoplankton concentration was an order of magnitude higher than in February (6.91 \pm $1.54 \times 10^{4}$ cells cm$~^{-3}$ ). The non-photosynthetic bacterial population also increased 4 -fold in July $(1.64 \pm 0.52 \times$ $10^{6}$ cells $\mathrm{cm}^{-3}$ ), and a third bacterial population (HNAhs, Table 1, Fig. 1A) was present in relatively high numbers $\left(1.4 \pm 0.4 \times 10^{5}\right.$ cells $\left.\mathrm{cm}^{-3}\right)$. However, the mean size of LNA and HNA-ls cells was 27 and $48 \%$ lower in July than in February, respectively, while their side scatter and nucleic acid content (green fluorescence) remained essentially the same.

\section{Plankton removal}

Considering all ultraplanktonic cells $(<10 \mu \mathrm{m})$, the filtration efficiency of Rhabdocalyptus dawsoni was high during both February $(94 \pm 2 \%$ ) and July (83 \pm $7 \%$ ). Feeding by Aphrocallistes vastus was measured 
Table 1. Ambient concentration $\left(\times 1000 \mathrm{ml}^{-1}\right)$, optical characteristics, and filtration efficiencies of the 5 planktonic populations and of sediment and detrital particles (LDet) during the 3 inhaled/exhaled feeding experiments. Values (average \pm SD) were determined using flow cytometry; optical properties are normalized to the values of $1 \mu \mathrm{m}$ beads. In February 2004, the experiment was repeated twice with 5 specimens of Rhabdocalyptus dawsoni. In July 2004 the experiment was repeated 3 times with 3 specimens of $R$. dawsoni and 5 times with 5 specimens of Aphrocallistes vastus. Filtration efficiency statistics were calculated over specimen averages. Green fluorescence is a proxy of nucleic acid content. Forward scatter normalized to the forward scatter of $1.0 \mu \mathrm{m}$ beads is a proxy of size. LNA: low nucleic acid content; HNA-ls: high nucleic acid content, low light scatter; HNA-hs: high nucleic acid content, high light scatter

\begin{tabular}{|c|c|c|c|c|c|c|c|c|c|}
\hline & \multicolumn{3}{|c|}{ LNA } & \multicolumn{3}{|c|}{ - HNA-ls } & \multicolumn{2}{|r|}{ - HNA-hs - } & \multirow{3}{*}{$\begin{array}{l}\text { A. vastus } \\
\text { Jul }\end{array}$} \\
\hline & \multicolumn{2}{|c|}{ R. dawsoni } & \multirow{2}{*}{$\begin{array}{l}\text { A. vastus } \\
\text { Jul }\end{array}$} & \multicolumn{2}{|c|}{ R. dawsoni } & \multirow{2}{*}{$\begin{array}{l}\text { A. vastus } \\
\text { Jul }\end{array}$} & \multicolumn{2}{|c|}{ R. dawsoni } & \\
\hline & Feb & Jul & & Feb & Jul & & Feb & Jul & \\
\hline Ambient conc. & $191 \pm 19$ & $428 \pm 164$ & $443 \pm 98$ & $171 \pm 21$ & $1191 \pm 392$ & $738 \pm 151$ & $11 \pm 0$ & $136 \pm 42$ & $180 \pm 117$ \\
\hline $\begin{array}{l}\text { Forward scatter } \\
\text { (size, } \mu \mathrm{m})\end{array}$ & $0.3 \pm 0.1$ & $0.2 \pm 0.0$ & $0.2 \pm 0.0$ & $0.4 \pm 0.0$ & $0.3 \pm 0.1$ & $0.3 \pm 0.0$ & $0.4 \pm 0.0$ & $0.4 \pm 0.0$ & $0.4 \pm 0.0$ \\
\hline Side scatter & $0.02 \pm 0.00$ & $0.02 \pm 0.00$ & $0.02 \pm 0.00$ & $0.02 \pm 0.00$ & $0.02 \pm 0.00$ & $0.02 \pm 0.00$ & $0.09 \pm 0.00$ & $0.13 \pm 0.02$ & $0.14 \pm 0.02$ \\
\hline Green fluorescence & $0.1 \pm 0.0$ & $0.1 \pm 0.0$ & $0.1 \pm 0.0$ & $0.2 \pm 0.0$ & $0.2 \pm 0.0$ & $0.2 \pm 0.0$ & $0.3 \pm 0.0$ & $0.5 \pm 0.0$ & $0.4 \pm 0.1$ \\
\hline \multirow[t]{4}{*}{$\%$ removed } & $92 \pm 2$ & $93 \pm 3$ & $84 \pm 12$ & $97 \pm 0$ & $89 \pm 5$ & $82 \pm 14$ & $92 \pm 3$ & $17 \pm 18$ & $35 \pm 12$ \\
\hline & \multicolumn{3}{|c|}{ Synechococcus } & \multicolumn{3}{|c|}{ Eukaryotic algae } & \multirow{2}{*}{\multicolumn{2}{|c|}{$\begin{array}{l}\text { R. dawsoni } \\
\text { LDet }-\end{array}$}} & \multirow{3}{*}{$\begin{array}{l}\text { A. vastus } \\
\text { Jul }\end{array}$} \\
\hline & \multicolumn{2}{|c|}{ R. dawsoni } & \multirow{2}{*}{$\begin{array}{l}\text { A. vastus } \\
\text { Jul }\end{array}$} & \multicolumn{2}{|c|}{ R. dawsoni } & \multirow{2}{*}{$\begin{array}{l}\text { A. vastus } \\
\text { Jul }\end{array}$} & & & \\
\hline & Feb & Jul & & Feb & Jul & & Feb & Jul & \\
\hline Ambient conc. & $3 \pm 0$ & $57 \pm 14$ & $59 \pm 3$ & $4 \pm 0$ & $13 \pm 4$ & $8 \pm 1$ & $2 \pm 1$ & $105 \pm 13$ & $64 \pm 7$ \\
\hline $\begin{array}{l}\text { Forward scatter } \\
\text { (size, } \mu \mathrm{m})\end{array}$ & $1.4 \pm 0.1$ & $1.2 \pm 0.1$ & $1.3 \pm 0.1$ & $3.6 \pm 0.3$ & $4.1 \pm 0.5$ & $3.8 \pm 0.5$ & $26.1 \pm 3.1$ & $8.6 \pm 1.6$ & $9.6 \pm 0.7$ \\
\hline Side scatter & $0.1 \pm 0.0$ & $0.1 \pm 0.0$ & $0.1 \pm 0.0$ & $0.4 \pm 0.1$ & $0.4 \pm 0.0$ & $0.5 \pm 0.0$ & $9.9 \pm 1.7$ & $1.8 \pm 0.3$ & $2.0 \pm 0.2$ \\
\hline Green fluorescence & $2.3 \pm 0.3$ & $2.2 \pm 0.3$ & $4.1 \pm 0.3$ & $14.0 \pm 2.6$ & $18.6 \pm 1.7$ & $25.7 \pm 2.6$ & $3.7 \pm 1.0$ & $1.5 \pm 0.1$ & $1.7 \pm 0.1$ \\
\hline$\%$ removed & $80 \pm 3$ & $86 \pm 15$ & $68 \pm 11$ & $91 \pm 1$ & $84 \pm 11$ & $82 \pm 11$ & $-76 \pm 60$ & $-6 \pm 46$ & $-43 \pm 23$ \\
\hline
\end{tabular}
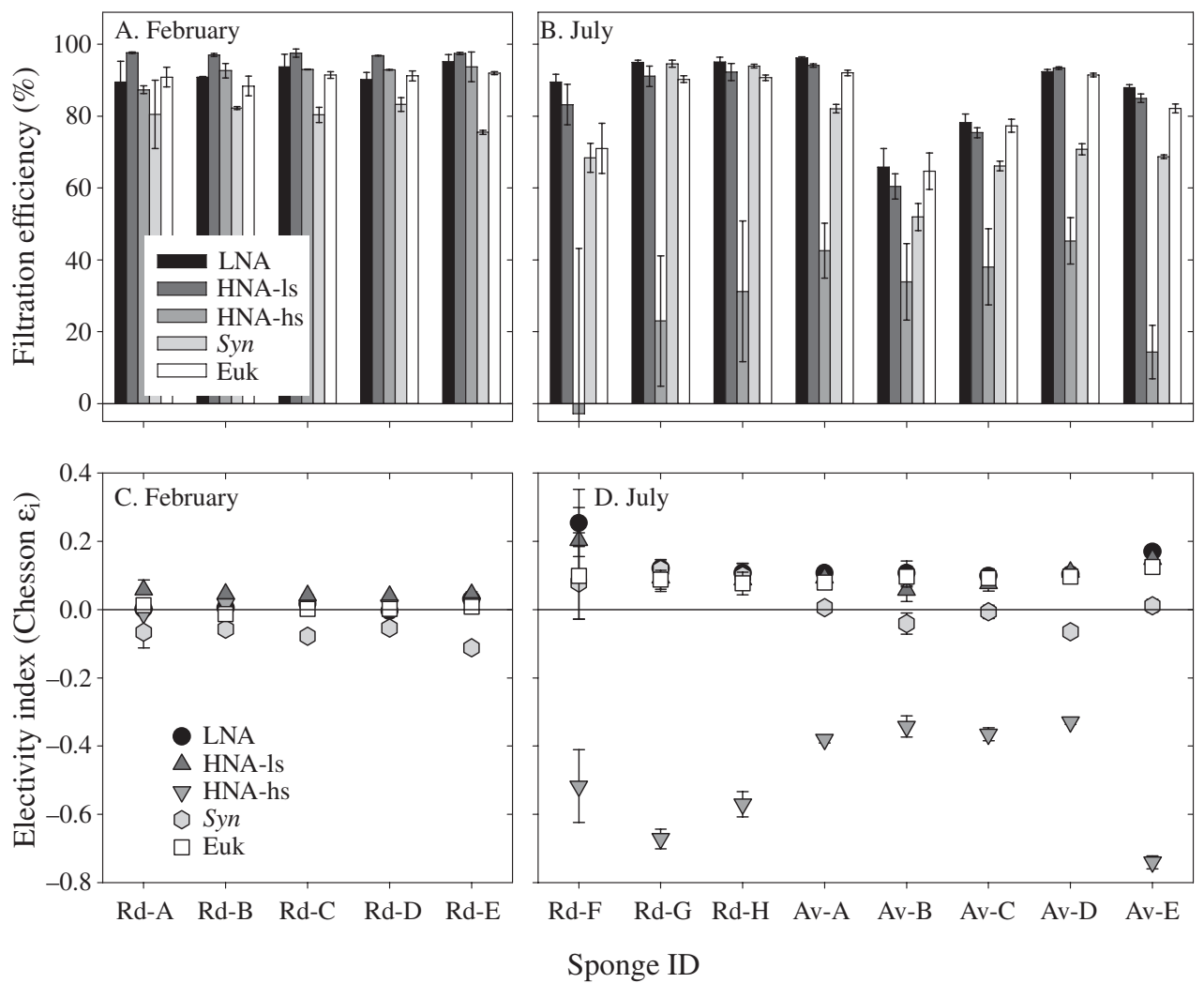

Fig. 2. Filtration efficiencies $(\mathrm{A}, \mathrm{B})$ for different ultraplanktonic prey taxa and $(\mathrm{C}, \mathrm{D})$ the corresponding electivity coefficients $\left(\varepsilon_{i}\right)$ calculated for each of the 13 sponge specimens sampled (8 Rhabdocalyptus dawsoni [Rd-A to - $\mathrm{H}$ ] and 5 Aphrocallistes vastus [Av-A to -E]). (A) and (C), February 2004; (B) and (D), July 2004. Chesson $\alpha_{i}$ s (Chesson 1978) were rescaled to $\varepsilon_{i}$ so that it would be independent of the number of prey types available (Chesson 1983). $\varepsilon_{i}$ ranges from -1 , when none of the ith prey type is taken, to 1 when the ith prey type is the only one selected for. Zero is the expected value for $\varepsilon_{i}$ if there is no preference (Chesson 1983). Error bars $= \pm$ SE. LNA: low nucleic acid content; HNA-ls: high nucleic acid content, low light scatter; HNA-hs: high nucleic acid content, high light scatter 


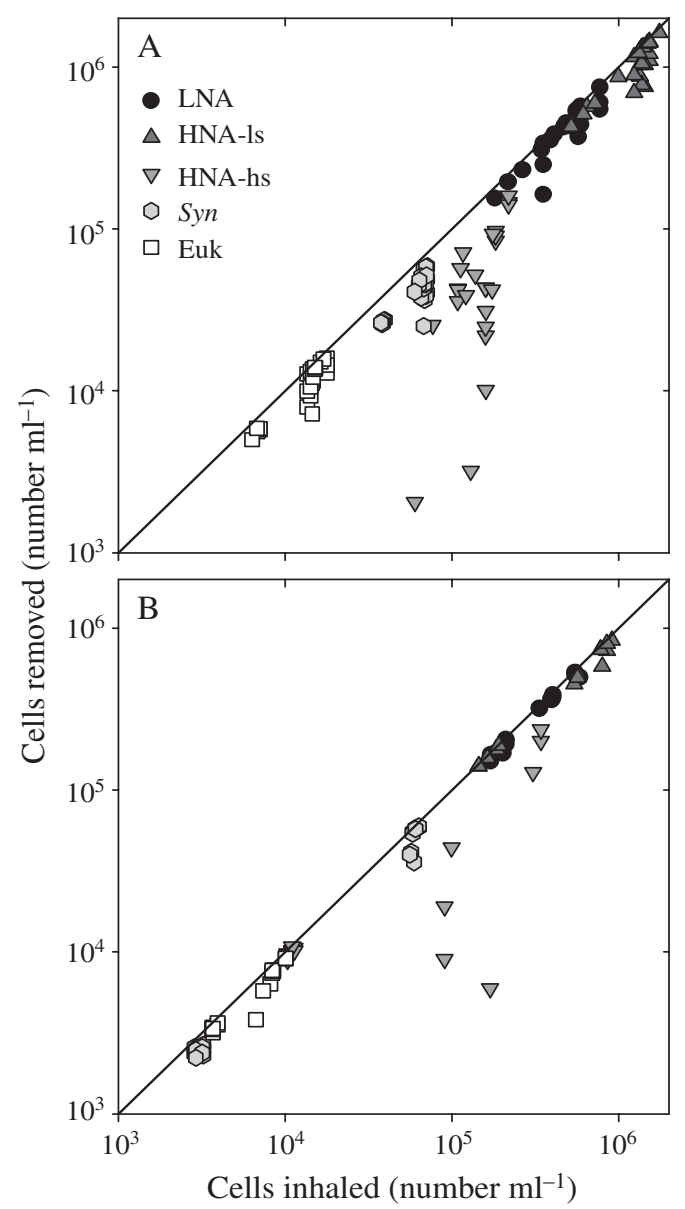

Fig. 3. (A) Aphrocallistes vastus and (B) Rhabdocalyptus dawsoni. Removal of ultraplanktonic cells (concentration difference between inhaled and exhaled water) plotted as a function of average inhaled concentrations for each paired water sample. Note the logarithmic scales of both axes. For each prey taxon, the February 2004 data can be distinguished from the July data by their lower ambient concentration. The diagonal line $(x=y)$ represents $100 \%$ filtration

only in July and its total filtration efficiency $(78 \pm 12 \%)$ during that time was comparable to that of $R$. dawsoni. Electron microscopy of paired water samples from the July experiments indicated that inhaled water samples contained several small diatom species $(<12 \mu \mathrm{m})$, coccolithophorids, and a variety of unidentified naked cells. Intact cells comprised up to $50 \%$ of the particles $(>1 \mu \mathrm{m})$ in inhaled water samples. In contrast, only 2 intact cells (diatoms) were found in the exhaled water samples, whereas the presence of broken/stripped frustules and cellular debris was much higher.

Individual sponge specimens differed in their filtration efficiency (Fig. 2A,B), but the preference pattern of each specimen was remarkably consistent among repeated runs (see the small error bars in Fig. 2A,B). This consistency of individual specimen performance was demonstrated by the lack of significant differences between the runs in each of the separate Doubly RM ANOVA for the 3 experiments (we used 'Runs' as the first factor with 2 to 5 levels and 'Prey type' as the second factor with 5 levels, $\mathrm{p}>0.1$ ). Therefore, specimen data were pooled across runs and specimen means were used for subsequent analysis. An RM ANOVA over all specimen means revealed a significant difference between the filtration efficiency of the different planktonic prey types (Wilks' $\lambda=0.07, F_{4,7}=22.6, \mathrm{p}<$ 0.001 ). However, significant interaction terms indicated that this pattern differed between the 2 sampling seasons (Wilks' $\lambda=0.03, F_{4,7}=67.7, \mathrm{p}<0.001$ ) and between the 2 sponge species (Wilks' $\lambda=0.14, F_{4,7}=$ $10.5, \mathrm{p}=0.004)$. Similar results were also obtained for $\alpha_{i}$. Therefore, the differences between the 2 sponge species were compared only within the July experiment, while differences between seasons were compared only for Rhabdocalyptus dawsoni.

\section{Rhabdocalyptus dawsoni}

The filtration efficiencies of Rhabdocalyptus dawsoni specimens during the February experiment were generally high (>90\%), except for a slightly less efficient removal of the photosynthetic cyanobacteria Synechococcus ( $80 \pm 3 \%$, Fig. 2A). Small non-photosynthetic bacteria (HNA-ls) were the most preferred prey type (filtration efficiency range 96 to $99 \%$, Fig. 2A). Comparison of $\alpha_{i}$ indicated that this preference was highly significant $\left(F_{1,4}=205.0, \mathrm{p}<0.001\right.$, Fig. 2 C). For Synechococcus, a negative selection was observed, with $\alpha_{i}$ being significantly lower than the expected value for no selectivity $\left(F_{1,4}=50.5, p=0.002\right.$, Fig. $\left.2 C\right)$.

When exposed to the post bloom ultraplankton community of July 2004, Rhabdocalyptus dawsoni filtration patterns were significantly different from those in February $\left(F_{1,6}=14,532, \mathrm{p}<0.001\right)$. This difference was primarily due to a dramatic reduction in the filtration of the largest non-photosynthetic bacterial population, HNA-hs (Fig. 2B,D). Cells falling in the HNA-hs cluster were removed in February at 86 to $98 \%$ efficiency whereas in July, filtration efficiency averaged $17 \%$ (Table 1). During the July experiments, the smallest non-photosynthetic bacterial population (LNA) was retained at the highest efficiency $(92 \pm 2 \%)$, but its retention was not significantly different from the filtration efficiency of HNA-ls ( $86 \pm 5 \%$, Table 1, Fig. 2B). Overall, plankton filtration efficiency was independent of ambient plankton concentrations or cell sizes, and taxa with intermediate size and abundance were the least preferred prey (Fig. 3A). R. dawsoni was somewhat more efficient and more selective than Aphrocallistes vastus (see below). 


\section{Aphrocallistes vastus}

Aphrocallistes vastus showed high selectivity (RM ANOVA, $F_{4,16}=29.8, \mathrm{p}<0.001$ ) and its preference pattern resembled that of Rhabdocalyptus dawsoni (Fig. 2B,D). Comparison of $\alpha_{i}$ for the July experiments showed no significant difference or interaction between prey type and sponge species (RM ANOVA, $\left.F_{1,6}=0.64, \mathrm{p}=0.46\right)$. As for $R$. dawsoni, the intermediate sized non-photosynthetic bacteria belonging to the HNA-hs population were the least preferred cell type (filtration efficiency $35 \pm 12 \%$ ). Synechococcus cyanobacteria were also significantly less preferred (post-hoc pairwise comparison, $\mathrm{p}<0.003$ ) in comparison to both smaller and larger cells (LNA and HNA-ls bacteria and eukaryotic algae, respectively, Table 1). In comparison to $R$. dawsoni, A. vastus filtration efficiencies tended to be somewhat lower (Table 1, Fig. 2B,D) and discrimination against the HNA-hs population was less dramatic, resulting in a significant interaction term between prey type and sponge species for the July experiment (RM ANOVA, Wilks' $\lambda=$ 0.038, $F_{4,3}=19.1, \mathrm{p}=0.018$ ). Similar to $R$. dawsoni, the plankton filtration efficiency of $A$. vastus was independent of the ambient plankton concentrations, with the least preferred taxa having intermediate abundances (Fig. 3B).

\section{Sediment and detrital particles}

Flow cytometry, electron microscopy, and EDX microanalysis of paired water samples from the July experiments indicated that inhaled water samples contained a large proportion of inorganic clays and silt as well as clay aggregates, often with broken diatom frustules. Particles in the cluster we named LDet (Fig. 1E, see 'Materials and methods') were characterized by a low ratio of red and green fluorescence to light scatter, corresponding to low (or nil) chlorophyll and nucleic acid content, respectively. SEM-EDX analysis of sorted LDet particles indicated that this cluster contained 50 to $70 \%$ clay/silt aggregates, 20 to $50 \%$ broken diatom frustules and other cellular debris, and 0 to $17 \%$ unidentified particles of mixed (organic/inorganic) composition. SEM-EDX analysis also indicated that a large proportion of the particles falling outside of the LDet cluster definitions were also composed of clays, clay aggregates, and debris. In some exhaled water samples, up to $82 \%$ of the non-living particles detectable with the flow cytometer were outside the LDet region (Fig. 1E,D).

LDet particles were not removed by the sponge (Table 1); in fact, the concentration of the LDet particles was elevated in all paired samples taken from
Aphrocallistes vastus in July and from Rhabdocalyptus dawsoni in February, but in only a third of the paired samples obtained from $R$. dawsoni in July. Ambient LDet concentration was much higher in July in comparison to February (Table 1). The concentration of LDet in the exhaled water sample was positively correlated to the total inhaled plankton concentration ( $\mathrm{r}=$ 0.89, $\mathrm{p}<0.001$ ); however, when the partial correlation was calculated, taking into account the effect of inhaled LDet concentration, this correlation was deemed insignificant $(r=0.32, p=0.31)$.

\section{DISCUSSION}

The idea that sponges are non-selective filter feeders stems from the presumption that the sponge collar microvilli are one of the few examples of a true filter (Riisgård \& Larsen 2001). Despite interpretations of non-selectivity by sponges that persist in the literature (Alexander 1979, Pile \& Young 1999, Kowalke 2000), data in some of these papers (e.g. Fig. 2B in Pile et al. 1996, and Fig. 2 in Kowalke 2000) suggest clear differential retention of particles. Furthermore, a growing literature shows that selective retention does occur in many sponges. A preference for smaller particles was reported by Reiswig (1971), Frost (1980), and Witte et al. (1997), whereas Turon et al. (1997) report that 2 Mediterranean demosponges retained $1 \mu \mathrm{m}$ latex beads at higher efficiency in comparison to both smaller (0.5 and $0.2 \mu \mathrm{m})$ and larger $(4 \mu \mathrm{m})$ beads. Wilkinson et al. (1984) used radioactive labeling to demonstrate discrimination between symbiotic and 'food-type' bacteria in 2 tropical sponges. Some of the above ambiguity on selective feeding in sponges may stem from the ability of some demosponges to ingest (into specialized phagocytes) many types of particles (reviewed by Witte et al. 1997) and subsequently release unwanted items into the exhalent currents (Wilkinson et al. 1984).

\section{Glass sponge diet and selectivity}

The natural diet of glass sponges (Hexactinellida) has been difficult to study because of their deep habitat and the difficulty of controlling for arrests of the feeding current in field studies (Reiswig 1990, Perez 1996, Wyeth et al. 1996, Wyeth 1999). In this study, we exposed the glass sponges Aphrocallistes vastus and Rhabdocalyptus dawsoni to a wide range of prey types including ultraphytoplankton, naturally available only to the uppermost sponge populations. Both species efficiently filtered and retained ultraplanktonic cells 
while debris and suspended sediment were expelled into the exhaled waters (Table 1, Fig. 1C,E,F). Moreover, both glass sponges exhibit strong, size independent, discrimination among ultraplanktonic prey types (Figs. 1 \& 2, Table 1).

\section{Biomass consideration}

We estimated the relative contribution of the different food types using relative cell sizes and general carbon/volume relationships suggested for protists (Menden-Deuer \& Lessard 2000) and bacteria (Gundersen et al. 2002). These calculations indicate that eukaryotic algae accounted for the bulk of the ultraplanktonic biomass (>70 and $>80 \%$ during the July and February 2004 experiments, respectively). Synechococcus accounted for an additional $\sim 15 \%$ of the total ultraplanktonic carbon in July and for $\sim 5 \%$ in February. Therefore, the contribution of non-photosynthetic bacterial biomass was relatively small $(<15 \%)$ in both seasons. The less preferred bacterial population (HNA-hs) accounted for up to $46 \%$ of the non-photosynthetic bacteria biomass in July (average $25 \pm 9 \%$ ), but only for $7 \pm 3 \%$ of the total bacterial biomass in February.

\section{Phytoplankton}

The water used in this study was pumped from the bottom of the photic zone (Taylor \& Haigh 1996), close to the upper limit of glass sponge distribution (Leys et al. 2004). During the February experiment, nonphotosynthetic bacteria concentration $(3.7 \pm 0.4 \times$ $10^{5}$ cells $\mathrm{cm}^{-3}$ ) was about a third of the concentrations reported by Yahel et al. (2007) for the deep sponge habitat $\left(8.4 \pm 2.2 \times 10^{5}\right.$ cells $\left.\mathrm{cm}^{-3}\right)$, whereas values were 2 times higher $\left(16.4 \pm 5.2 \times 10^{5}\right.$ cells $\left.\mathrm{cm}^{-3}\right)$ during the July experiments. The most prominent difference between the laboratory experiments reported here and the field measurements of Yahel et al. (2007) was the demonstration of sponge ability to feed on phytoplankton when present in the ambient water. The efficient filtration of phytoplankton suggests that the potential nutritional niche of the studied glass sponges is much wider than that realized by the bulk of the population that resides well below the photic zone. Glass sponges living at or near the photic zone will benefit from a potential increase of 5 - to 10 -fold in the amount of carbon and nutrient obtained for each liter of water they process. Other factors such as silica, light and temperature are likely to limit the glass sponge distribution to below the photic zone (Leys et al. 2004).
Non-photosynthetic bacteria

It is now well accepted that cytometric clusters are correlated with phylogenetic association and metabolic activity (e.g. Zubkov et al. 2001). The LNA, HNAls and HNA-hs non-photosynthetic bacterial populations in our samples roughly correspond to the LNA and low protein, HNA and low protein, and HNA and high protein groups defined by Zubkov et al. (2001) for the Celtic Sea. Using in situ hybridization techniques, Zubkov et al. (2001) demonstrated that $\gamma$-proteobacteria from the SAR86 cluster were associated with their LNA cytometric population. The HNA-ls population was associated mostly with members of the Cytophaga-Flavobacterium cluster, and the HNA-hs population was dominated by the $\gamma$-proteobacteria genus Roseobacter. Subsequent work has demonstrated similar phylogenetic affiliation of flow cytometry-sorted bacteria for other localities such as the coastal waters off Plymouth, UK (Zubkov et al. 2004), and the North Sea (Zubkov et al. 2002). Comparison of the ultraplankton population in our summer water samples (July 2004) with the winter samples (February) indicates large shifts in abundance and optical properties (Table 1), suggesting a shift in the taxonomic composition and/or the metabolic status of each population seasonally. Members of the Roseobacter lineage are known to increase their abundance during the summer and in association with algal blooms. Many of these lineage members produce potent toxins or other secondary metabolites (Buchan et al. 2005). As the phylogenetic identity of the different cytometric populations is not known, it is premature to speculate why the population of HNA-hs was less preferred in July 2004.

\section{Synechococcus}

The pattern of preference for Synechococcus cyanobacteria varied between seasons and among the 2 sponge species: Rhabdocalyptus dawsoni selected against Synechococcus in February but not in July (Table 1, Fig. 2), whereas Aphrocallistes vastus selected against Synechococcus during the July experiments (Fig. 2). This negative selection for Synechococcus by hexactinellid sponges is intriguing as Synechococcus and Prochlorococcus appear to be the most preferred prey type by those marine demosponges examined so far (Pile et al. 1996, Pile 1999, 2005, Ribes et al. 1999, Yahel et al. 2003, 2005). Synechococcus was also preferentially removed from the water flowing over coral reefs (van Duyl et al. 2002). In contrast, recent grazing studies in pelagic oligotrophic waters suggest that these cells are the least grazed by planktonic consumers (e.g. Sommer et al. 2002) and Syne- 
chococcus was also the least preferred prey type of 2 freshwater sponges from Lake Baikal, Russia (Pile et al. 1997).

\section{Suspended sediment and detritus}

Glass sponges, like most other benthic suspension feeders, need to cope with an extremely diluted suspension of food particles dominated by inorganic, indigestible particles. At the sponges' habitat, the benthic boundary layer seston is dominated by inorganic particles $\left(\sim 7 \mathrm{mg} \mathrm{l}^{-1}\right.$, >97\% of suspended solids, Yahel et al. 2007). In a coarse clay dominated seston $(\sim 1 \mu \mathrm{m})$, these levels correspond to $>5 \times 10^{7}$ particles $\mathrm{cm}^{-3}$ (Kirk \& Gilbert 1990), an order of magnitude higher than the ultra-planktonic cell concentration available to the sponges (max. $2.4 \times 10^{6}$ cells $\mathrm{cm}^{-3}$ ). While high concentrations of inorganic seston can be detrimental for some suspension feeders such as cladocerans (Kirk \& Gilbert 1990) and bivalves (Cranford \& Gordon 1992), other taxa such as rotifers seem to be unaffected (Kirk \& Gilbert 1990). Bivalves use pre-ingestion sorting and eliminate unwanted particles as pseudo-faeces to avoid the burden of ingestion and digestion of large masses of suspended sediments (Cranford \& Gordon 1992, Ward \& Shumway 2004). Our knowledge of the fate of indigestible food particles inhaled by sponges is rudimentary (Wolfrath \& Barthel 1989).

Both Rhabdocalyptus dawsoni and Aphrocallistes vastus selected against inorganic and debris particles (Fig. 1, Table 1). We used the well-defined cluster of LDet (Fig. 1) particles as an indicator of the fate of indigestible particles inhaled by the sponges.

As suggested by the SEM analysis, the increased concentration of LDet particles in most exhaled water samples can be partially attributed to the 'transformation' of intact armored cells (e.g. diatoms, coccolithophorids) into stripped shells. Wolfrath \& Barthel (1989) report that the demosponge Halichondria panicea packages singly ingested particles into spherical aggregates held together by a thin cover. Only edible remnants were packaged into fecal pellets, whereas indigestible particles were egested as single particles and also passed more rapidly through the sponge (Wolfrath \& Barthel 1989). Microscopical analysis of exhaled water samples in our study revealed only a few fecal-pellet-like aggregates, composed mostly of crushed diatom frustules and cellular debris. However, it is plausible that delicate aggregates making up fecal pellets disintegrated during sample preservation and handling.

It should be noted that LDet particles were relatively large ( 7 to $10 \mu \mathrm{m}$ in July, larger in February) and the total concentration of the LDet particles never exceeded $1.5 \times 10^{5}$ particles $\mathrm{cm}^{-3}$ in the ambient water ( $<15 \%$ of total ultraplanktonic cells). Therefore the LDet population comprises only a small fraction of the total number of non-living particles in the water. In many cases the LDet cluster accounted for $<20 \%$ of the total non-living seston detectable with the flow cytometer (e.g. Fig. 1E).

\section{Filtration mechanism}

The details of the filtration mechanism in sponges are not well understood. In demosponges, dermal pores (ostia) vary in size from 10 to $200 \mu \mathrm{m}$, canals are 20 to $200 \mu \mathrm{m}$ in diameter, and prosopyles (pores leading into the flagellated chambers) are 2 to $5 \mu \mathrm{m}$ in diameter (Reiswig 1975a). The collar filter unit does not seal the chamber in many demosponges (e.g. Langenbruch \& Scaleraliaci 1986), and it is possible that particles not trapped by the collar (whose mesh size is approximately $0.1 \mu \mathrm{m}$ ) could escape the sponge filter (see also Leys \& Eerkes-Medrano 2006).

In principle, the hexactinellid filter is similar to that of demosponges. The pores in the syncytial dermal membrane (surface inhalant tissue) are only 20 to $30 \mu \mathrm{m}$ in diameter, incurrent canals are large (up to $1 \mathrm{~mm}$ in diameter) initially, but taper to $200 \mu \mathrm{m}$ diameter as they near the choanocyte chambers, much as in demosponges. The collar microvilli are only $0.1 \mu \mathrm{m}$ in diameter, and are spaced 0.1 to $0.2 \mu \mathrm{m}$ apart (Fig. 4A). Microvilli are joined by a double layer of glycocalyx mesh with 20 to $200 \mathrm{~nm}$ diameter pores (Mackie \& Singla 1983). The most obvious difference, apart from the syncytial tissue organization and enucleate collar bodies (see Mackie \& Singla 1983), is the large size of choanocyte chambers (up to $60 \mu \mathrm{m}$ inner diameter, $120 \mu \mathrm{m}$ outer diameter) and the presence of a secondary reticulum supporting the collars (Reiswig 1979, Leys 1999, Fig. 4). Except for instances where prosopyles of the primary and secondary reticula line up (see Leys 1999) this reticulum appears to effectively prevent passage of particles except through the collar microvilli (Fig. 4), presumably making the hexactinellid filter very efficient (Reiswig 1979).

The existence of bypasses, 'merging between the incurrent and excurrent systems bypassing the choanocyte chambers', has been suggested for both demosponges and glass sponges (Bavestrello et al. 2003, and references therein). It is hard to reconcile the high filtration efficiencies we observed with the existence of such bypass routes. Moreover, considering the ultrastructure of the glass sponge filtration apparatus, it is hard to imagine a physical process that would allow sorting and differential retention of micron sized particles such as HNA-ls vs. HNA-hs bacteria using 

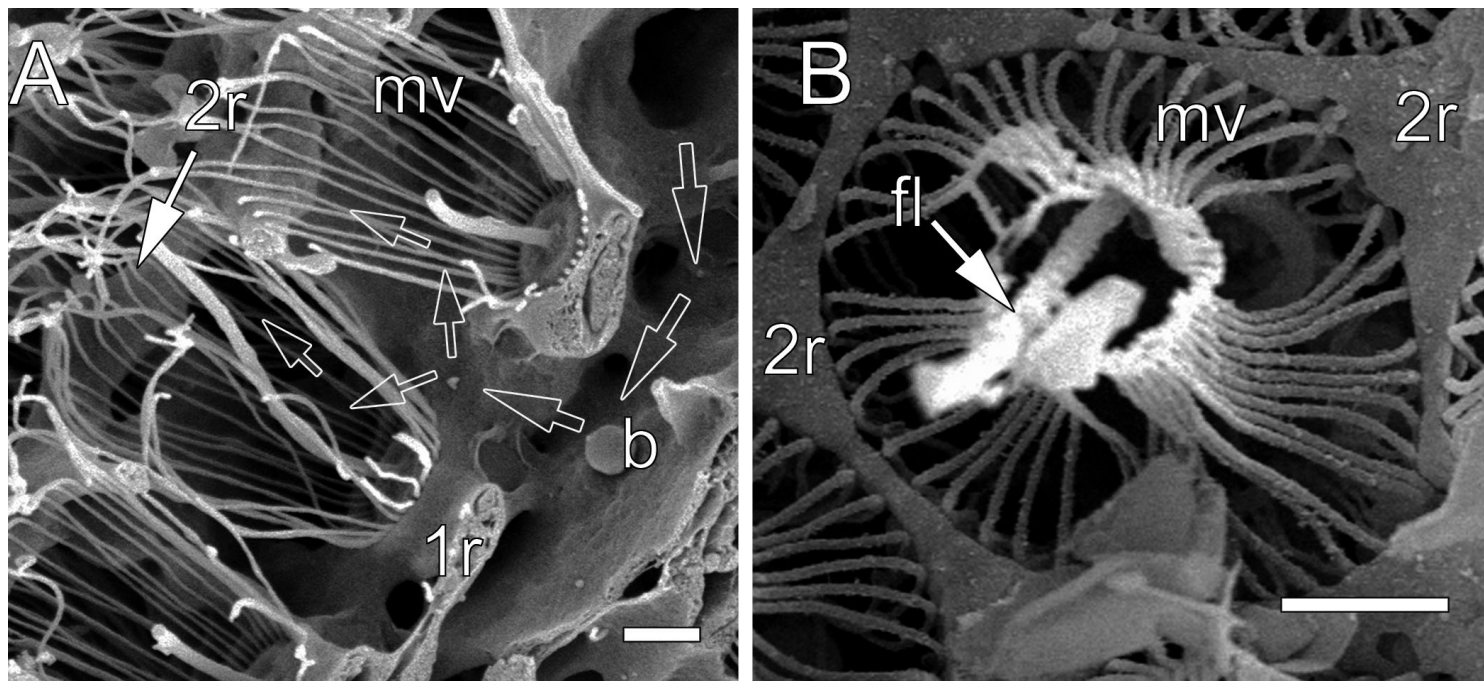

Fig. 4. Aphrocallistes vastus. Scanning electron micrographs of the filtration apparatus showing the flagellum (fl) enclosed by the ring of collar microvilli (mv) and the position of the primary (1r) and secondary reticula (2r). Note that the secondary reticulum abuts the microvilli collar and prevents material from escaping the filter. (A) Fractured specimen showing a side view with white arrows showing putative water and particle pathways from the inhalant canals and through the collar (b, $1 \mu \mathrm{m}$ latex bead). Open arrows indicate the putative water path. (B) Top view

hydrodynamics. The high filtration efficiency observed for some cell populations suggests that the vast majority of particles larger than 0.1 to $0.2 \mu \mathrm{m}$ are trapped by the sponge filter. These results suggest that particle selection in hexactinellids takes place post capture. Sponges do not possess digestive organs and digestion takes place intracellularly within food vacuoles. Preingestion sorting may occur within the trabecular reticulum. Indigestible and unwanted particles captured by this tissue may be transported directly through to the exhaled water while preferred food particles may be similarly transported into food vacuoles. Alternatively, the sponge may not actively select cells intracellulary, but rather some cell types could resist breakdown and pass through the food vacuoles intact (e.g. Van Donk et al. 1997).

The existence of bypass routes can be tested experimentally by 'feeding' the glass sponges with readily identifiable indigestible particles (e.g. fluorescent beads) in a dye solution (e.g. sodium fluorescein). Coappearance of the dye and beads in the exhaled water would confirm the existence of bypasses. Alternatively, if the beads were to appear a few minutes after addition of the dye, this would support the model suggested here of individual trapping and processing of each particle (G. O. Mackie pers. comm.).

One consequence of the individual particle processing proposed here is that the cellular processes involved (endocytosis, intracellular transport, and exocytosis) potentially introduce a significant time delay between the ingestion and egestion of sestonic particles. While our simultaneous sampling scheme ensures accurate detection of changes in dissolved water constituents, it may have introduced bias in the comparison of the particulate input and output of the sponges. This is particularly relevant in July when sampling time was brief (a few minutes) and less likely in February when the large volume of water collected and the prolonged sampling duration $(>10 \mathrm{~h})$ ensure proper integration of the inherent plankton patchiness. To examine if the lack of genuine pairing of the inhaled and exhaled water samples may have biased our results, we calculated the sponge filtration efficiencies for the July experiment using the averages of the 5 inhaled and 5 exhaled water measurements obtained for each specimen to compute single removal efficiency and a single $\alpha_{i}$ value for each planktonic population (see Fig. 5). This analysis confirms there is negative selection against the HNA-hs bacteria $(\alpha=0.1 \pm 0.04$ and $0.09 \pm 0.02$ for Aphrocallistes vastus and Rhabdocalyptus dawsoni, respectively) and Synechococcus by $A$. vastus $(\alpha=0.19 \pm 0.01)$ but not $R$. dawsoni $(\alpha=0.22 \pm 0.02)$. RM ANOVA indicated that removal efficiency of different planktonic prey differed significantly for both A. vastus $\left(F_{4,16}=32.7, \mathrm{p}<0.001\right)$ and $R$. dawsoni $\left(F_{4,8}=61.1, \mathrm{p}<0.001\right)$. Student-Newman-Keuls posthoc pairwise multiple comparisons indicated that the removal of the HNA-hs population was significantly lower $(p<0.05)$ than all other prey types in both sponge species, whereas the removal of Synechococcus was significantly lower in comparison to Eukaryotic algae and the LNA and HNA-ls bacteria for $A$. vastus but not for $R$. dawsoni. 


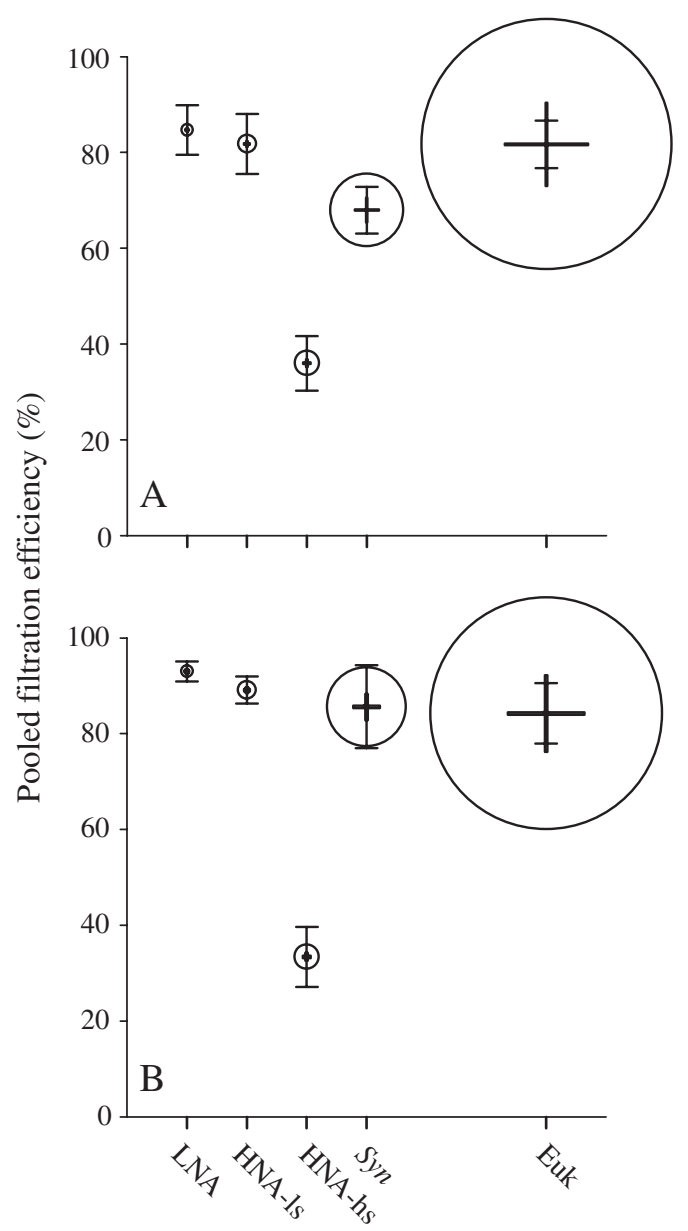

Fig. 5. (A) Aphrocallistes vastus and (B) Rhabdocalyptus dawsoni. Average removal efficiencies (\%) of the different planktonic prey populations recalculated from pooled data of the July experiment assuming no pairing between simultaneous inhaled and exhaled samples. For each sponge specimen we average all inhaled and all exhaled measurements $(n=5)$ and calculated a single (per specimen) removable efficiency value for each planktonic population as $100 \times \overline{\ln }-\overline{E X} / \overline{I n}$, where $\overline{I n}$ is the average inhaled concentration and $\overline{E x}$ is the average exhaled concentration. Symbol size indicates the relative size of the respective planktonic prey. Error bars $= \pm \mathrm{SE}$

Sponges filter a vast volume of water (see Table 3 in Yahel et al. 2003 for demosponge values) and thus process a huge number of particles daily. With such throughput is it possible for individual sorting of particles to occur? Indeed, considering typical bacterial concentrations of $0.8 \times 10^{5}$ cells $\mathrm{ml}^{-1}$ and a specific pumping rate of $1.3 \mathrm{~cm}^{3} \mathrm{~s}^{-1} \mathrm{~cm}^{-3}$ sponge tissue, $1 \mathrm{~cm}^{2}$ of A. vastus wall would process $\sim 10^{9}$ bacteria $\mathrm{d}^{-1}$ (corresponding to an excurrent velocity of $1 \mathrm{~cm} \mathrm{~s}^{-1}$ based on in situ pumping Acoustic Doppler Velocimeter measurements, Yahel et al. 2007, G. Yahel unpubl. data). However, considering a typical flagellated chamber (external diameter $\sim 120 \mu \mathrm{m}$ ) that contains about
2750 collar bodies and a flagellated chamber density of $\sim 50 \%$ of the sponge volume, the collar unit density in a typical Aphrocallistes vastus is $\sim 1.5 \times 10^{9} \mathrm{~cm}^{-3}$ (H. M. Reiswig pers. comm.). Therefore, each collar unit is expected to encounter $\sim 1$ bacterium and possibly 10 indigestible particles per day. This low encounter rate could presumably give the syncytial tissue sufficient time to individually process and select particles upon encounter.

We suggest that unlike most suspension feeders (Rubenstein \& Koehl 1996, Riisgård \& Larsen 2001), including some sponges (Leys \& Eerkes-Medrano 2006), the filtration apparatus of the glass sponges studied does resemble a true sieve. We conclude that the selective retention we observed involves individual processing, recognition, sorting, and transport of each particle through the sponges' syncytial tissue. This assertion is supported by observations of capture and processing of bacteria and $1 \mu \mathrm{m}$ latex beads by the hexactinellids Rhabdocalyptus dawsoni (Wyeth et al. 1996, Wyeth 1999) and Oopsacas minuta (Perez 1996).

Acknowledgements. We thank H. M. Reiswig for his invaluable help in electron microscopy, data analysis and interpretation, V. Tunnicliffe and G. Mackie for valuable discussions and suggestions, J. M. Rose, R. and L. Yahel, and L. Haines, for their professional and dedicated help with portions of the work; ROPOS team, and the Captain and crew of CCGS J. P. Tully for the sponge collection. Access to analytical instrumentation and facilities was kindly provided by T. W. Pearson, L. Haines (FACSCalibur, UVic), J. S. Taylor (Olympus BX61), A. Johnston (FACS Vantage, UBC), and the Bamfield Marine Science Center. Funding support includes Rothschild fellowship (to G.Y.), NSERC studentship (to D.I.E.) and NSERC Discovery program to Verena Tunnicliffe and Henry Reiswig (University of Victoria), and NSERC Ship Time and Discovery program grants (to S.P.L.) (University of Alberta).

\section{LITERATURE CITED}

Alexander RM (1979) The invertebrates. Cambridge University Press, Cambridge

Bavestrello G, Arillo A, Calcinai B, Cerrano C (2003) The aquiferous system of Scolymastra joubini (Porifera, Hexactinellida) studied by corrosion casts. Zoomorphology 122:119-123

Boyd I (1981) The spicule jungle of Rhabdocalyptus dawsoni: a unique microhabitat. Honours Thesis, University of Victoria, Victoria, BC

Buchan A, Gonzalez JM, Moran MA (2005) Overview of the marine Roseobacter lineage. Appl Environ Microbiol 71: 5665-5677

Cavender-Bares KK, Rinaldo A, Chisholm SW (2001) Microbial size spectra from natural and nutrient enriched ecosystems. Limnol Oceanogr 46:778-789

Chesson J (1978) Measuring preference in selective predation. Ecology 59:211-215

Chesson J (1983) The estimation and analysis of preference and its relationship to foraging models. Ecology 64:1297-1304

Conway KW, Barrie JV, Austin WC, Luternauer JL (1991) Holocene sponge bioherms on the Western Canadian Continental Shelf. Cont Shelf Res 11:771-790 
Conway KW, Krautter M, Barrie JV, Neuweiller M (2001) Hexactinellid sponge reefs on the Canadian continental shelf: a unique 'living fossil'. Geoscience Can 28:71-78

Cranford PJ, Gordon DC (1992) The influence of dilute clay suspensions on sea scallop (Placopecten-magellanicus) feeding-activity and tissue-growth. Neth J Sea Res 30: 107-120

Dayton PK, Robillia G, Paine RT, Dayton LB (1974) Biological accommodation in benthic community at McMurdo Sound, Antarctica. Ecol Monogr 44:105-128

Diaz MC, Rutzler K (2001) Sponges: an essential component of Caribbean coral reefs. Bull Mar Sci 69:535-546

Diaz MC, Ward BB (1997) Sponge-mediated nitrification in tropical benthic communities. Mar Ecol Prog Ser 156: 97-107

Eerkes-Medrano DI, Leys SP (2006) Ultrastructure and embryonic development of a syconoid calcareous sponge. Invertebr Biol 125:177-194

Frost TM (1980) Selection in sponge feeding processes. In: Smith DC, Tiffon Y (eds) Nutrition in the lower Metazoa. Pergamon Press, Oxford, p 33-44

Gast GJ, Wiegman S, Wieringa E, van Duyl FC, Bak RPM (1998) Bacteria in coral reef water types: removal of cells, stimulation of growth and mineralization. Mar Ecol Prog Ser 167:37-45

Ghiold J (1991) The sponges that spanned europe. New Sci 129:58-62

Gili JM, Bibiloni MA, Montserrat A (1984) Water-pumping activity and bacterial retention rates 'in situ', of three species of littoral sponges. Preliminary study. Misc Zool 8: $13-21$

Gundersen K, Heldal M, Norland S, Purdie DA, Knap AH (2002) Elemental C, N, and P cell content of individual bacteria collected at the Bermuda Atlantic Time-Series Study (BATS) site. Limnol Oceanogr 47:1525-1530

Hoffmann F, Larsen O, Thiel V, Rapp HT, Pape T, Michaelis W, Reitner J (2005) An anaerobic world in sponges. Geomicrobiol J 22:1-10

Jørgensen CB (1966) Biology of suspension feeding. Pergamon Press, London

Kirk KL, Gilbert JJ (1990) Suspended clay and the populationdynamics of planktonic rotifers and cladocerans. Ecology 71:1741-1755

Kowalke J (2000) Ecology and energetics of two Antarctic sponges. J Exp Mar Biol Ecol 247:85-97

Krautter M, Conway KW, Barrie JV, Neuweiler M (2001) Discovery of a 'Living dinosaur': Globally unique modern hexactinellid sponge reefs off British Columbia, Canada. Facies 44:265-282

Langenbruch PF, Scaleraliaci L (1986) Body structure of marine sponges. 4. Aquiferous system and choanocyte chambers in Haliclona elegans (Porifera, Demospongiae). Zoomorphology 106:205-211

Leppard GG, West MM, Flannigan DT, Carson J, Lott JNA (1997) A classification scheme for marine organic colloids in the Adriatic Sea: colloid speciation by transmission electron microscopy. Can J Fish Aquat Sci 54:2334-2349

Leys SP (1999) The choanosome of hexactinellid sponges. Invertebr Biol 118:221-235

Leys SP, Eerkes-Medrano DI (2006) Feeding in a Calcareous sponge: particle uptake by pseudopodia. Biol Bull 211:157-171

Leys SP, Lauzon NRJ (1998) Hexactinellid sponge ecology: growth rates and seasonality in deep water sponges. J Exp Mar Biol Ecol 230:111-129

Leys SP, Mackie GO, Meech RW (1999) Impulse conduction in a sponge. J Exp Biol 202:1139-1150
Leys S, Tompkins GJ (2004) Glass sponges arrest pumping in response to increased sediment loads. Integr Comp Biol 44:719-719

Leys SP, Wilson K, Holeton C, Reiswig HM, Austin WC, Tunnicliffe V (2004) Patterns of glass sponge (Porifera, Hexactinellida) distribution in coastal waters of British Columbia, Canada. Mar Ecol Prog Ser 283:133-149

Mackie GO, Singla CL (1983) Studies on hexactinellid sponges. I. Histology of Rhabdocalyptus dawsoni (Lambe, 1873). Phil Trans R Soc Lond B 301:365-400

Marie D, Partensky F, Jacquet S, Vaulot D (1997) Enumeration and cell cycle analysis of natural populations of marine picoplankton by flow cytometry using the nucleic acid stain SYBR green I. Appl Environ Microbiol 63:186-193

Marie D, Brussaard CPD, Partensky F, Vaulot D (1999) Flow cytometric analysis of phytoplankton, bacteria and viruses. In: Robinson JP (ed) Current protocols in cytometry. John Wiley \& Sons, New York, p 11.11.11-11.11.15

Menden-Deuer S, Lessard EJ (2000) Carbon to volume relationships for dinoflagellates, diatoms, and other protist plankton. Limnol Oceanogr 45:569-579

Perez T (1996) Particle uptake by a hexactinellid sponge, Oopsacas minuta (Leucopsacasidae): the role of the reticulum. CR Acad Sci Ser III 319:385-391

Pernthaler J (2005) Predation on prokaryotes in the water column and its ecological implications. Nat Rev Microbiol 3: $537-546$

Pile AJ (1997) Finding Reiswig's missing carbon: quantification of sponge feeding using dual-beam flow cytometry. Proc 8th Int Coral Reef Symp Panama, June 24-29, 1996. Smithsonian Tropical Research Institute, Universidad de Panama, p 1403-1410

Pile AJ (1999) Resource partitioning by Caribbean coral reef sponges: is there enough food for everyone? Mem Qld Mus 4:457-461

Pile AJ (2005) Overlap in diet between co-occurring active suspension feeders on tropical and temperate reefs. Bull Mar Sci 76:743-749

Pile AJ, Young CM (1999) Plankton availability and retention efficiencies of cold-seep symbiotic mussels. Limnol Oceanogr 44:1833-1839

Pile AJ, Patterson MR, Witman JD (1996) In situ grazing on plankton $<10 \mu \mathrm{m}$ by the boreal sponge Mycale lingua. Mar Ecol Prog Ser 141:95-102

Pile AJ, Patterson MR, Savarese M, Chernykh VI, Fialkov VA (1997) Trophic effects of sponge feeding within Lake Baikal's littoral zone: 2. Sponge abundance, diet, feeding efficiency, and carbon flux. Limnol Oceanogr 42:178-184

Pile AJ, Grant A, Hinde R, Borowitzka MA (2003) Heterotrophy on ultraplankton communities is an important source of nitrogen for a sponge-rhodophyte symbiosis. J Exp Biol 206:4533-4538

Reiswig HM (1971) Particle feeding in natural population of three marine Demosponges. Biol Bull (Woods Hole) 141:568-591

Reiswig HM (1975a) The aquiferous systems of three marine Demospongiae. J Morphol 145:493-502

Reiswig HM (1975b) Bacteria as food for temperate-water marine sponges. Can J Zool 533:582-589

Reiswig HM (1979) Histology of hexactinellida (Porifera). Coll Int Centre Natl Rech Sci 291:173-180

Reiswig HM (1981) Partial carbon and energy budgets of the bacteriosponge Verongia fistularis (Porifera: Demospongiae) in Barabados. PSZN I: Mar Ecol 2:273-293

Reiswig HM (1990) In situ feeding in two shallow-water Hexactinellid sponges. In: Rutzler K (ed) New perspectives in sponge biology. Smithsonian Institution Press, Washington, DC, p 504-510 
Ribes M, Coma R, Gili JM (1999) Natural diet and grazing rate of the temperate sponge Dysidea avara (Demospongiae, Dendroceratida) throughout an annual cycle. Mar Ecol Prog Ser 176:179-190

Ribes M, Coma R, Atkinson MJ, Kinzie RA (2005) Sponges and ascidians control removal of particulate organic nitrogen from coral reef water. Limnol Oceanogr 50:1480-1489

Richter C, Wunsch M, Rasheed M, Kotter I, Badran MI (2001) Endoscopic exploration of Red Sea coral reefs reveals dense populations of cavity-dwelling sponges. Nature 413:726-730

Riisgård HU (2001) On measurement of filtration rates in bivalves - the stony road to reliable data: review and interpretation. Mar Ecol Prog Ser 211:275-291

Riisgård HU, Larsen PS (2001) Minireview: ciliary filter feeding and bio-fluid mechanics-present understanding and unsolved problems. Limnol Oceanogr 46:882-891

Robertson BR, Button DK, Koch AL (1998) Determination of the biomasses of small bacteria at low concentrations in a mixture of species with forward light scatter measurements by flow cytometry. Appl Environ Microbiol 64: 3900-3909

Rubenstein DI, Koehl MAR (1996) The mechnisms of filter feeding: some theoretical consideration. Am Nat 111: 981-994

Sara M (1971) Ultrastructural aspects of the symbiosis between two species of the genus Aphanocapsa (Cyanophyceae) and Ircinia variabilis (Demospongiae). Mar Biol $11: 214-221$

Scheffers SR (2005) Benthic-pelagic coupling in coral reefs: interaction between framework cavities and reef water. $\mathrm{PhD}$ thesis, University of Amsterdam

Scheffers SR, Bak RPM, van Duyl FC (2005) Why is bacterioplankton growth in coral reef framework cavities enhanced? Mar Ecol Prog Ser 299:89-99

Seymour JR, Patten N, Bourne DG, Mitchell JG (2005) Spatial dynamics of virus-like particles and heterotrophic bacteria within a shallow coral reef system. Mar Ecol Prog Ser 288: $1-8$

Shalapyonok A, Olson RJ, Shalapyonok LS (2001) Arabian Sea phytoplankton during Southwest and Northeast Monsoons 1995: composition, size structure and biomass from individual cell properties measured by flow cytometry. Deep-Sea Res 48:1231-1261

Sommer U, Berninger UG, Bottger-Schnack R, Cornils A and 8 others (2002) Grazing during early spring in the Gulf of Aqaba and the Northern Red Sea. Mar Ecol Prog Ser 239: 251-261

Taylor FJR, Haigh R (1996) Spatial and temporal distributions of microplankton during the summers of 1992-1993 in Barkley Sound, British Columbia, with emphasis on harmful species. Can J Fish Aquat Sci 53:2310-2322

Turon X, Galera J, Uriz MJ (1997) Clearance rates and aquiferous systems in two sponges with contrasting life-history strategies. J Exp Zool 278:22-36

Vacelet J, Bouryesnault N, Fialamedioni A, Fisher CR (1995) A methanotrophic carnivorous sponge. Nature 377: 296-296

Van Donk E, Luerling M, Hessen DO, Lokhorst GM (1997) Altered cell wall morphology in nutrient-deficient phytoplankton and its impact on grazers. Limnol Oceanogr 42:357-364

van Duyl FC, Gast GJ (2001) Linkage of small-scale spatial variations in DOC, inorganic nutrients and bacterioplankton growth with different coral reef water types. Aquat Microb Ecol 24:17-26

van Duyl FC, Gast GJ, Steinhoff W, Kloff S, Veldhuis MJW, Bak RPM (2002) Factors influencing the short-term varia-

Editorial responsibility: Urania Christaki,

Wimereux, France tion in phytoplankton composition and biomass in coral reef waters. Coral Reefs 21:293-306

Vaulot D (1989) CYTOPC: processing software for flow cytometric data. Signal Noise 2:8

Vyver GVD, Vray B, Belaouane S, Toussaint D (1985) Efficiency and selectivity of microorganism retention by Ephydatia fluviatilis. In: Rutzler K (ed) New perspectives in sponge biology. Smithsonian Institution Press, Washington, DC, p 511-515

Ward JE, Shumway SE (2004) Separating the grain from the chaff: particle selection in suspension- and deposit-feeding bivalves. J Exp Mar Biol Ecol 300:83-130

Wilkinson CR (1983) Net primary productivity in coral reef sponges. Science 219:410-412

Wilkinson CR, Garrone R (1980) Nutrition in marine sponges. Involvement of symbiotic bacteria in the uptake of dissolved carbon. In: Smith DC, Tiffon Y (eds) Nutrition in the lower Metazoa. Pergamon Press, Oxford, p 157-161

Wilkinson CR, Garrone R, Vacelet J (1984) Marine sponges discriminate between food bacteria and bacterial symbionts: electron microscopy, autoradiography, and in situ evidence. Proc R Soc Lond Ser B 220:519-528

Witte U, Brattegard T, Graf G, Springer B (1997) Particle capture and deposition by deep sea sponges from the Norwegian-Greenland Sea. Mar Ecol Prog Ser 154: 241-252

Wolfrath B, Barthel D (1989) Production of faecal pellets by the marine sponge Halichondria panicea Pallas (1766). J Exp Mar Biol Ecol 129:81-94

Wright SH, Stephens GC (1978) Removal of amino acid during a single passage of water across the gill of marine mussels. J Exp Zool 205:337-352

Wyeth RC (1999) Video and electron microscopy of particle feeding in sandwich cultures of the hexactinellid sponge, Rhabdocalyptus dawsoni. Invertebr Biol 118:236-242

Wyeth RC, Leys SP, Mackie GO (1996) Use of sandwich cultures for the study of feeding in the hexactinellid sponge Rhabdocalyptus dawsoni (Lambe, 1892). Acta Zool 77 : 227-232

Yahel G, Post AF, Fabricius KE, Marie D, Vaulot D, Genin A (1998) Phytoplankton distribution and grazing near coral reefs. Limnol Oceanogr 43:551-563

Yahel G, Sharp JH, Marie D, Hase C, Genin A (2003) In situ feeding and element removal in the symbiont-bearing sponge Theonella swinhoei: bulk DOC is the major source for carbon. Limnol Oceanogr 48:141-149

Yahel G, Marie D, Genin A (2005) InEx - a direct in situ method to measure filtration rates, nutrition, and metabolism of active suspension feeders. Limnol Oceanogr Met 3: 46-58

Yahel G, Whitney F, Reiswig HM, Eerkes-Medrano DI, Leys SP (2007) In situ feeding and metabolism of glass sponges (Hexactinellida, Porifera) studied in a deep temperate fjord with a remotely operated submersible. Limnol Oceanogr 52:(in press)

Zubkov MV, Fuchs BM, Burkill PH, Amann R (2001) Comparison of cellular and biomass specific activities of dominant bacterioplankton groups in stratified waters of the Celtic Sea. Appl Environ Microbiol 67:5210-5218

Zubkov MV, Fuchs BM, Tarran GA, Burkill PH, Amann R (2002) Mesoscale distribution of dominant bacterioplankton groups in the northern North Sea in early summer. Aquat Microb Ecol 29:135-144

Zubkov MV, Allen JI, Fuchs BM (2004) Coexistence of dominant groups in marine bacterioplankton community - a combination of experimental and modelling approaches. J Mar Biol Assoc UK 84:519-529

Submitted: February 4, 2006; Accepted: September 13, 2006 Proofs received from author(s):November 9, 2006 